\title{
Governance of technological change: lessons from the Japanese experience
}

Citation for published version (APA):

Yarime, M., \& Parto, S. (2005). Governance of technological change: lessons from the Japanese experience. MERIT, Maastricht Economic Research Institute on Innovation and Technology. MERITInfonomics Research Memorandum Series No. 031 https://doi.org/10.26481/umamer.2005031

Document status and date:

Published: 01/01/2005

DOI:

10.26481/umamer.2005031

Document Version:

Publisher's PDF, also known as Version of record

\section{Please check the document version of this publication:}

- A submitted manuscript is the version of the article upon submission and before peer-review. There can be important differences between the submitted version and the official published version of record. People interested in the research are advised to contact the author for the final version of the publication, or visit the DOI to the publisher's website.

- The final author version and the galley proof are versions of the publication after peer review.

- The final published version features the final layout of the paper including the volume, issue and page numbers.

Link to publication

\footnotetext{
General rights rights.

- You may freely distribute the URL identifying the publication in the public portal. please follow below link for the End User Agreement:

www.umlib.nl/taverne-license

Take down policy

If you believe that this document breaches copyright please contact us at:

repository@maastrichtuniversity.nl

providing details and we will investigate your claim.
}

Copyright and moral rights for the publications made accessible in the public portal are retained by the authors and/or other copyright owners and it is a condition of accessing publications that users recognise and abide by the legal requirements associated with these

- Users may download and print one copy of any publication from the public portal for the purpose of private study or research.

- You may not further distribute the material or use it for any profit-making activity or commercial gain

If the publication is distributed under the terms of Article $25 \mathrm{fa}$ of the Dutch Copyright Act, indicated by the "Taverne" license above, 


\section{MERIT-Infonomics Research Memorandum series}

\section{Governance of Technological Change:}

Lessons from the Japanese Experience

\section{Masaru Yarime \& Saeed Parto}

\section{5-031}

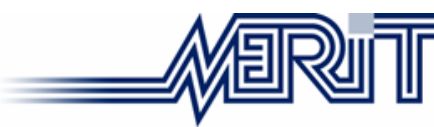

MERIT - Maastricht Economic Research Institute on Innovation and Technology

PO Box 616

6200 MD Maastricht

The Netherlands

$\mathrm{T}:+31433883875$

F: +31 433884905

http://www.merit.unimaas.nl e-mail:secr-merit@merit.unimaas.nl

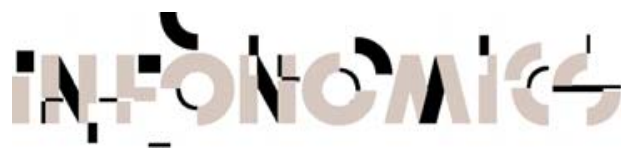

International Institute of Infonomics

c/o Maastricht University

PO Box 616

6200 MD Maastricht

The Netherlands

$\mathrm{T}:+31433883875$

F: +31 453884905

http://www.infonomics.nl

e-mail: secr@infonomics.nl 


\title{
Governance of Technological Change: Lessons from the Japanese Experience Masaru Yarime ${ }^{1}$ and Saeed Parto ${ }^{2}$
}

\begin{abstract}
The outbreak of the Minamata disease in 1956 started a process of transformation in the Japanese chlor-alkali industry. Since then the industry has undergone two significant technological transformations. The first was from the mercury-based process to the diaphragm process while the second was from the diaphragm process to the ion membrane process. The pressure on the industry to adopt the diaphragm process was not without its problems: the technology produced inferior quality product at higher cost and posed the risk of market share loss for the producers. The attempts by the government and industry to find an economically viable solution resulted in the adoption by the industry of the ion membrane process, a technology that was non-polluting, comparable to the mercury process in terms of costs, and produced high quality product. In this paper we examine the dynamics of this technological transformation to draw out and discuss generalizable implications for environmental policymaking. We elucidate the importance of collective learning and innovation in the policymaking process to address acute and complex socio-economic problems. In particular, we draw attention to the role of the main institutions through which this technological change was governed.
\end{abstract}

JEL Codes: L52, L65, O33, O38

Keywords: Technical Change, Policy Learning, Governance, Institutions

\footnotetext{
${ }^{1}$ Research Center for Advanced Science and Technology, University of Tokyo, Tokyo, Japan (yarime@nistep.go.jp ).

${ }^{2}$ United Nations University, Institute for New Technologies (UNU-INTECH), Maastricht, The Netherlands ( parto@intech.unu.edu ).
} 


\section{Introduction}

In May 1956, four cases of an unknown disease with nervous symptoms were reported in Minamata in the southern part of Japan. Further investigations revealed that more patients were suffering from the same symptoms among the inhabitants in the Minamata Bay area. Although heavy metals such as selenium, manganese, and thallium were initially suspected as the agent causing the disease, the disease was proved to be methyl mercury poisoning caused by ingestion of seafood caught in the Minamata Bay and the neighboring seas and hence the name "Minamata disease" (Tsubaki and Irukayama, 1977). By the end of 1972 there were at least 700 Minamata disease patients and the general public was voicing concerns about seawater pollution. In May 1973 a newspaper article suggested that a case of Minamata disease was discovered in the Ariake Sea area in Kyushu (Asahi Shinbun, 1973a). Just one month later the same newspaper reported a similar incident which happened near Tokuyama Bay in the western part of Japan (Asahi Shinbun, 1973b). As both cases were linked to industrial complexes with chlor-alkali operations, pressure was mounting on the government to stop mercury emissions from these plants, although there was no scientific evidence to support the allegations.

Fishermen organized demonstrations against mercury-based chlor-alkali plants in coastal areas throughout Japan, and some of the plants were actually forced to halt operation. The Environmental Agency, which had been established just two years earlier, organized the Health Examination Committee and conducted medical examination of inhabitants of nine marine areas, including the Ariake Sea and Tokuyama Bay areas. The conclusion was that no case of the Minamata disease or methyl mercury poisoning was found in any area other than Minamata Bay and its neighboring seas (Irukayama, 1977). However, public pressure for immediate action was so fierce that the Japanese government was prompted to take measures to cut mercury emissions. The Council for the Promotion of Countermeasures against Mercury Pollution (Countermeasures Council), set up in 1973, decreed the installation of a closed system for effluents containing mercury by the end of September 1974.

The pressure on the industry to adopt the diaphragm process was not without its problems: the technology produced inferior quality product at higher costs and posed the risk of market share loss for the producers. In a 1977 consultative meeting of the industry with the Countermeasures Council it was reported that a new promising technology (the ion exchange membrane process) that was being developed had the potential of producing high quality product at lower costs. In light of these developments the conversion programme to the diaphragm process was suspended until evaluation could be made on the feasibility of the ion exchange membrane process. By the year 2000 over $95 \%$ of the industry had adopted the ion exchange membrane process.

In this paper we examine the dynamics of this technological transformation to draw out and discuss generalizable implications for environmental policymaking. We elucidate the importance of collective learning and innovation in the policymaking process to address acute and complex socio-economic problems. In particular, we draw attention to the role of the main institutions through which this technological change was governed. The 
remainder of this paper is structured as follows. In the next section we discuss the concept of transitions, followed by a discussion of institutions and their role in facilitating transitions. A description of the chlor-alkali industry and the technologies in use in that industry is used to highlight the dynamics that led to the emergence of the new technological regime. The dynamics of technological change are analyzed through the concept of transition and a typology of institutions (Parto 2005) to draw out and discuss generalizable implications for environmental policy conducive to innovation.

\section{What are "Transitions"?}

A transition is a process of change through which society, or a subsystem of society such as an industrial sector, moves to a different stable state. Transitions are induced through interplays of social, economic, ecological, technological and institutional developments (Rotmans et al. 2000). Transitions may also be viewed as evolutionary phenomena embodied in systemic processes that combine new and old elements to generate a new regime or state through a relatively rapid and sometimes chaotic process. The concept of transition thus articulated is firmly rooted in the development of complex systems (Nicolis and Prigogine 1977, 1989; Kay 1991). The development of complex systems is characterized by phases of rapid (re)organization leading to relative stability, which after a period of relative calm tend to become destabilized and move toward rapid reorganization to constitute a new dynamic equilibrium.

In addition, each new state has elements or remnants of past states and thus there are no entirely "new" states. Some dynamic equilibria may be more stable than others, however. A transition occurs when a new (significantly different) dynamic equilibrium is reached. The occurrence of a transition is intertwined with a series of inter-related institutional changes in and between the dynamic equilibria. A societal transition usually takes 25 years or longer and results from a coming together of a set of developments in different domains to constitute a new dynamic equilibrium significantly different from the previous equilibria. Drawing on conceptualizations of systems dynamics and “demographic transitions” (Davis 1945), Rotmans et al. (2001) hypothesize that transitions consist of the following stages:

A predevelopment phase of dynamic equilibrium where the status quo does not visibly change.

A take-off phase where the process of change gets under way because the state of the system begins to shift.

A breakthrough phase where visible structural changes take place through an accumulation of socio-cultural, economic, ecological and institutional changes that react to each other. During the acceleration phase, there are collective learning processes, diffusion and embedding processes.

A stabilization phase where the speed of social change decreases and a new dynamic equilibrium is reached.

In the predevelopment phase structures, routines, and repetitions characterize the subsystem and provide a certain degree of predictability of outcomes. The onset of 
change is evidenced through the occurrence of unprecedented events, a weakening of existing structures, and decreased repetition. "Events" may be significant social, environmental and economic problems, new visions, or innovation. The emergence and establishment of new structures and routines mark the beginnings of a new institutional order closely associated with a new dynamic equilibrium. These phases are consistent with Kay’s (1991) conceptualization of “thermodynamic branches” and Rostow’s (1960) "modernization theory". 3 A transition may be said to have occurred every time an optimum operating point is instituted in the subsystem. The subsystem may be an ecosystem (Kay 1991), an organization, a policy domain (Ostrom 1999, Sabatier and Jenkins-Smith 1999), a system of production and consumption, a group, a scientific discipline or a paradigm (Gersick 1991). ${ }^{4}$

Perceived in this manner, change is never entirely constituted of new elements. Rather, it is a product of the processes of variation and selection in which there is heredity and recombination of technologies, ideas, practices, routines, structures, organizations, and institutions. A stabilization trajectory or path (Figure 1) is the product of the institutionalization processes that precede it. The occurrence of a radical technology and its adoption by existing organizations, or the occurrence of surprises and breakdowns of existing technological regimes, are all events that can act as catalysts for specific processes of institutionalization that could result in a transition.

\section{Figure 1 about here}

A new technological trajectory sets in when structures are weakened through organizational fatigue and/or emergence of new "events" that act as stressors to the current technological regime. If the stress by events on the current regime persists, in all likelihood new trajectories will develop and lead to stabilization at one of many possible optimum operating points (Figure 1). In a socio-economic context, an optimum operating point in Figure 1 is produced through a coming together of scientific knowledge, production process technologies and practices, different types of institution, and infrastructure. Stability is traceable to specific, socially embedded bodies of knowledge, habits, norms, and forms, which collectively structure economic activity and policymaking. The move from one dynamic equilibrium (at the lower end of the S-curve in Figure 1) to the next (Paths 1, 2, or 3) is often the product of co-evolutionary processes characterized by the interplays between endogenous and exogenous factors, with each set of interplays resulting in a uniquely identifiable technological regime as represented by Paths 1, 2, and 3 in Figure $1 .^{5}$ The analysis of transitions from a policy perspective

\footnotetext{
${ }^{3}$ Rostow (1960) describes economic development as the passage of society through five evolutionary stages of: traditional society, the stage of the preconditions for take-off, the take-off stage, the drive to maturity, and the age of high consumption as exemplified by modern industrialized states. For a description of Key's (1991) thermodynamic branches in a transitions context see Parto (2003).

${ }^{4}$ In this paper metaphors and examples drawn from biology and ecology are used insofar as they deepen appreciation and understanding of socio-economic complexities. This selective utilization of other disciplines is consistent with Nelson and Winter's (1982:11) “Lamarchian” approach.

${ }^{5}$ The lower level of Path 1 in Figure 1 does not indicate superiority of the technological regimes represented by Paths 2 and 3.
} 
requires in-depth knowledge of these factors and the institutionalization processes that they may have set in motion.

\section{Analyzing Transitions}

A major part of our analysis of transitions is concerned with identifying the multiplicity of events that structure developments in a given subsystem. In Table 1 the column "Institution Type" describes the characteristics of the institutions that emerge as the products of the institutionalization processes set in motion by endogenous and exogenous catalytic events. To account for the role of institutions we identify the problems, events, actors, and other factors that collectively act as the catalysts of institutionalization processes that precede the emergence of new institutions and a new technological regime. We characterize a technological regime by the institutions that collectively structure inter-relations at the social, organizational, and societal levels (Table 1). ${ }^{6}$ A main part of our task in this paper is to present empirical examples for the institution types listed in Table 1 . The resulting inventory will be used to establish the linkages between different types of institution within the Japanese chlor-alkali industry and their role in the technological transitions in that sector. This inventory also allows us to examine the manner in which the identified institutions "mature" and transform into other types of institution.

To illustrate, business networks are usually characterized by certain values and codes of conduct. If the network persists over time the members of the network internalize some of the values and most of the codes of conduct become predictable routines. The internalization process occurs concurrently with the emergence of new or reinforced behavioural traits among the network members. Depending on the balance of power within the societal mode of governance (among other factors), the business network may become instrumental in effecting societal change through persistent lobbying or direct legal or other types of challenge to the status quo. At this point the network may be thought of as both "associative" for its network characteristics and "regulative" for its ability to prescribe and proscribe at a societal level specific values and codes of conduct.

\section{Table 1 about here}

We may thus summarize that institutions that shape interactions among economic agents are best viewed as multifaceted, durable but evolving social structures, made up of symbolic elements, social activities, and (sometimes) material resources. Institutions spread across systems or spheres, e.g., social, economic, political, and cultural; operate at

\footnotetext{
${ }^{6}$ These levels of inter-relation refer to those: 1) among individuals at large based on interpersonal interdependence where many actors are involved (social); 2) within organizations to secure internal cohesion and among organizations to maximize adaptability of individual organizations so as to make compatible respective operational unities and independence with de facto material and social interdependence on other organizations (organizational); and, 3) among operationally autonomous functional systems each with its own autopoietic codes, programmes, institutional logics and interests in self-reproduction (societal). See Parto (2005a) for a further discussion and details.
} 
and through all scales of governance ${ }^{7}$, e.g., subnational, national, and supra-national; and structure inter-relations at all levels, i.e., the social, organizational, and societal. Key to evolutionary institutional analysis is the identification of institution types and their role in effecting movement from one dynamic equilibrium to the next, as depicted by Paths 1,2 , and 3 in Figure 1. The typology in Table 1 is used later in this paper to arrange the institutions of the Japanese chlor-alkali into groups based on their functions and how they facilitated or curtailed change within that sector.

From a policy perspective, effecting transitions is contingent on the controllability of main factors (variables). A key component of action-oriented analysis is thus to identify the most significant variables of the subsystem and to determine the degree of controllability for each variable. Variables instrumental in effecting a transition are best characterized as multi-level, multi-scale, and multi-system. To do meaningful institutional analysis of transitions and to investigate context steering opportunities for transition to "desirable" outcomes this complexity needs to be simplified considerably. ${ }^{8}$ Transitions become apparent when one compares different periods of stability through historical accounts and analysis of quantitative empirical data. We view the Japanese chlor-alkali sector in much the same way as Kingdon (1984) viewed the aviation industry in the United States: We set out to identify problems, policies, and politics to explain when, how, and why significant changes occurred in the Japanese chlor-alkali industry over time.

\section{Three Production Technologies in the Chlor-Alkali Industry}

The chlor-alkali industry basically produces chlorine and caustic soda through electrolysis. An aqueous solution of sodium chloride (salt) is decomposed with direct current to produce chlorine, hydrogen, and sodium hydroxide, that is, caustic soda. Since the electrolytic production of chlorine and caustic soda depends on a large current of amount of electricity, the chlor-alkali industry is a major user of electric power, and indeed its unit consumption of electricity is the one of the largest, following the aluminium, carbide, and ferroalloy industries. The Japanese chlor-alkali industry, for instance, consumed approximately 10.7 billion kWh of electricity in 1996, accounting for $3 \%$ of the total industry consumption and $18 \%$ of the total chemical industry consumption (Japan Soda Industry Association, 1998). As energy cost accounts for a significant part of the total manufacturing cost, one of the major targets of innovative activities in the chlor-alkali industry has been to develop technologies to reduce energy consumption.

Currently, there are three types of electrolytic processes in use for commercial manufacturing of chlorine and caustic soda in the world: the mercury process, the diaphragm process, and the ion exchange membrane process. Each process represents a different method of keeping chlorine and the anode separate from the caustic soda and

\footnotetext{
${ }^{7}$ In this paper we define governance as "the way human societies organize themselves". See Parto (2005b) for further elaboration.

${ }^{8}$ However, simplifications must be rigorously reviewed and reassessed to avoid redundancy of assumptions and to ensure sound analysis.
} 
hydrogen produced, directly or indirectly, at the cathode. Mercury is used in the mercury process whereas the diaphragm process and the ion exchange membrane process do not involve any use of mercury, relying instead on diaphragm and ion exchange membrane, respectively.

\section{Figure}

Figure 2 shows the shares of the three processes in the chlor-alkali industry in Western Europe, the United States and Japan. In Western Europe, approximately $60 \%$ of the chlor-alkali plants are based on the mercury process. In the United States, more than $70 \%$ of the chlor-alkali plants are using the diaphragm process. In Japan, while there are no chlor-alkali plants based on the mercury process, the ion exchange membrane process has been adopted by more than $90 \%$ of the chlor-alkali plants. In Western Europe and the United States the diffusion of the ion exchange membrane process is limited to approximately $10 \%$.

\section{Figure 2 about here}

The mercury process and the diaphragm process for chlor-alkali production were invented almost in the same period, at the end of the 19th century. Since then, technologies for the mercury process had been mainly developed in Western Europe whereas U.S. companies had been involved in improving technologies for the diaphragm process. The Japanese chlor-alkali industry initially introduced both processes from Western Europe and the United States at the beginning of the 20th century. In the United States, after the end of the Second World War continued research established the diaphragm process as the dominant technology in that country. In contrast, research and development efforts were devoted to improving the mercury process in Western Europe and Japan. Technologies for the mercury process were improved further, and more chloralkali producers adopted the mercury process in these two regions. By the late 1960s, the mercury process had come to dominate the chlor-alkali industry in Japan as well as in Western Europe. Since regulations were introduced to limit emission of mercury to the environment, divergent courses of technological change have been observed in the chloralkali industry between Western Europe and Japan.

\section{Regulatory Decision on the Phase-out of the Mercury Process}

Having become attuned to the misery of the Minamata disease in 1972, the general public started to voice its concerns about seawater pollution. The Basic Law for Environmental Pollution Control had been enacted in August 1967, establishing environmental quality standards based on the designation of pollutants' target ranges, the liability of polluters, and the responsibilities of the national as well as local governments. Subsequent regulations set limits to control the levels of mercury released to the environment. The chlor-alkali industry, which was using a large amount of mercury in the 1960s, particularly received public attention although emissions from the industry did not include any trace of methyl mercury, the organic mercury which caused the Minamata 
disease. Without any organic substances involved in the relevant chemical reactions, there was no possibility for the formation of organic mercury within chlor-alkali plants. Nevertheless, in the presence of a significant degree of uncertainty in the scientific mechanism of the transformation of mercury in the environment, the Ministry of International Trade and Industry (MITI) started to investigate mercury uses in chloralkali plants in June 1968. In February 1969, all effluent release points from chlor-alkali plants based on the mercury process became subject to the Law for the Conservation of Water Quality in Public Areas (Japan Soda Industry Association, 1982). At this point the emphasis of the regulatory measures was on how to reduce, but not necessarily eliminate, mercury releases into the environment.

In the wake of the controversies triggered by newspaper reports on the spread of the Minamata disease, the government established the Council for the Promotion of Countermeasures against Mercury Pollution (Countermeasures Council) in the Environmental Agency in June 1973. It was chaired by the Minister of State for Environment, assisted by the Administrative Vice-Minister and the State Secretary for Environment, and consisted of members from twelve ministries and agencies in the government (Japanese Ministry of International Trade and Industry, 1979). At its first meeting the Countermeasures Council decided that the installation of the closed loop system for effluents containing mercury should be completed by the end of September 1974. To meet this objective, chlor-alkali producers were required to commit to converting as many mercury plants as possible to the diaphragm process by the end of September 1975.

To meet this objective, chlor-alkali producers were required to commit to converting as many mercury plants as possible to the diaphragm process, an alternative technology, by the end of September 1975. Criticizing the decision, the chlor-alkali industry association argued that there were many technical as well as economic difficulties in the conversion of the existing mercury plants to the diaphragm process and that the conversion would take a long period of time (Japan Soda Industry Association, 1973a). The objections by the industry were submitted to the Minister of the Environmental Agency when the representatives of the industry visited the Agency to discuss the issue (Japan Soda Industry Association, 1973b). Although the industry's objections were not accepted by the Minister, the Countermeasures Council agreed at its third meeting in November 1973 that only two thirds of the existing mercury plants would be converted to the diaphragm process by September 1975 and the remaining one third by March 1978 (Council for the Promotion of Countermeasures against Mercury Pollution, 1973). This decision meant immediate undertaking by many of the existing mercury plants to convert from the mercury process to the diaphragm process.

With a mandate to implement the Countermeasures Council's decision, the Committee for the Promotion of Process Conversion in the Soda Industry (Conversion Committee) was established in September 1973 as a private consulting body to the Director-General of MITI's Basic Industries Bureau. The members of the Conversion Committee were selected from banks, academics, journalists and industry to reflect the multiplicity of issues and diversity of stakeholder interests (Japan Soda Industry Association, 1974). 
Along with a subcommittee, three expert groups were organized on finance and tax, technology and regulation, and supply and demand coordination to have more detailed and informed discussions on the schedule and criteria for the process conversion program and the financial and tax incentives to support it. The criteria for the conversion of mercury plants set a limit for mercury consumption by the soda industry. The plants that exceeded the limit were to convert by September 1975 while those that did not exceed the limit had to convert by March 1978 (Japanese Ministry of International Trade and Industry, 1973). To support newly converted production facilities, tax reductions were also introduced (Japan Soda Industry Association, 1985). Initially the diaphragm process was the target of the tax reduction scheme but was subsequently expanded to include the ion exchange membrane process.

The official decision to phase-out the mercury process was made at a time when this process was the dominant technology for chlor-alkali production in Japan, accounting for 95\% of the total capacity (Japan Soda Industry Association, 1982). In replacing the mercury process, the only alternative technology available at that time was the diaphragm process, which was used for only $5 \%$ of the industry. As the regulatory schedule for process conversion required that two thirds of the mercury process plants must be converted to the diaphragm process just in two years, the affected firms had to imitate, rather than innovate, to convert their processes. Consequently, technologies necessary for the diaphragm process had to be adopted mostly from foreign companies. Reflecting the most advanced development of the diaphragm process in the U.S. at that time, many of the technologies adopted for the diaphragm process were provided by American suppliers.

As many mercury-based plants were converted to the diaphragm process, however, the concerns about the high production cost of the diaphragm process coupled with lower quality caustic soda came to affect the industry significantly. Many users who had previously purchased caustic soda produced by the mercury process demanded the same level of high quality for caustic soda. For about $25 \%$ of all the applications, caustic soda produced by the diaphragm process was considered not to be suitable, especially for the manufacture of rayon, a thin fiber with a diameter in the order of micro meters which was said to be weaker and more susceptible to breaking when produced using low quality caustic soda (Japan Soda Industry Association, 1982). As the demand for the poor-quality caustic soda was low, manufacturers who had already converted their plants to the diaphragm process had difficulties in selling their products to customers. They demanded a level playing-field, which meant that diaphragm and mercury plant operators should consume and sell caustic soda produced by the diaphragm and mercury processes in the same proportion by making barter trades between them. In response to these concerns, in June 1975 MITI issued an administrative guide according to which caustic soda producers were to submit their production plans every three months to the Ministry, which in turn revised the production plans based on its demand projection for the quarter and mediated the barter trades (Japanese Ministry of International Trade and Industry, 1975). 
Furthermore, the diaphragm process required higher energy inputs than the mercury process. The energy consumption of the diaphragm process was approximately 3,400 $\mathrm{kWh}$ per tonne of caustic soda, well above 3,200 kWh per tonne of caustic soda for the mercury process (Japan Soda Industry Association, 1975). The production costs escalated with the oil crisis of the early 1970s - the price of electricity almost tripled after the first phase of the energy crisis, from 3.10 yen/kWh in 1970 to 9.10 yen/kWh in 1977 (Japan Soda Industry Association, 1988). By the early 1980s, the electricity price for chlor-alkali producers had reached 14.80 yen/kWh, a level more than four times larger than the price at the beginning of the 1970s. As the cost of caustic soda produced at newly constructed diaphragm plants became significantly larger than that at the existing mercury plants, the barter trading system was modified in October 1976 to include financial compensation reflecting the cost difference. Under this arrangement mercury process operators compensated their counterparts using the diaphragm process (Japan Soda Industry Association, 1980a).

The first phase of the conversion program was completed in April 1976, half a year behind the schedule, due to the technical as well as economic problems. By that time the share of the diaphragm process had increased significantly to about $60 \%$ from less than $5 \%$ prior to the commencement of the conversion program. Chlor-alkali producers who were still operating mercury-based plants insisted that they did not have sufficient financial resources to conduct more process conversions and lobbied the ruling Liberal Democratic Party as well as MITI for postponing the implementation of the second phase of the process conversion program (Japan Soda Industry Association, 1979a). At the fourth meeting of the Countermeasures Council in May 1977, while the members were informed that the caustic soda produced by the diaphragm process had a low quality and thus was very difficult to use, it was reported that a newly developed process, the ion exchange membrane process, was in a process of rapid progress and that it was expected to be able to produce high-quality caustic soda. Taking into account the emergence of a new promising technology, the Countermeasures Council made a decision that the implementation of the second phase of the conversion program should be suspended until an appropriate evaluation could be made on the feasibility of the ion exchange membrane process for the whole industryl (Council for the Promotion of Countermeasures against Mercury Pollution, 1977).

\section{Emergence of the Ion Exchange Membrane Process}

The ion exchange membrane process operates in a similar way to the diaphragm process, with basically the same chemical reactions involving no use of mercury throughout the whole production process. However, the ion exchange membrane process, unlike the diaphragm processes, also produces the same high quality caustic as the mercury process. In contrast to the end-of-pipe technology, which is installed to reduce emissions of pollutant like mercury at the end of the production process, the ion exchange membrane process is a prime example of clean technology, eliminating inputs that generate pollutants at the end of the process. While ion exchange membranes determine the performance of electrolytic cells, including the current efficiency and cell voltage and hence energy consumption, they also need to have sufficient strength to withstand severe 
exposition to chlorine on one side and strong caustic on the other in electrolytic cells. Although the idea of the ion exchange membrane process for the production of chlorine and caustic soda had been known for many years, earlier work to further develop the technology had failed due to the non-availability of suitable ion exchange membranes which could resist the very demanding conditions within chlor-alkali cells. A significant amount of research and development effort was required to invent ion exchange membranes which would be suitable for chlor-alkali production.

To investigate the extent of innovative activities conducted by Japanese firms, the research for this paper analyzed data on patent applications on the ion exchange membrane process, along with those on the mercury and diaphragm processes. Figure 3 shows the trends in successful applications for Japanese patents by firms based in Japan from the late 1960s to the late 1980s. Patent data on technologies related to the mercury process were obtained from the data assembled by the Japan Soda Industry Association (Japan Soda Industry Association, 1982). The data set covers patents granted up to the end of the 1970s. Patents on technologies related to the diaphragm process and the ion exchange membrane process were selected by using the data set constructed by the industry association and shared by its member companies (Japan Soda Industry Association 1976, 1977, 1978b, 1978a, 1979b, 1991a, 1991b, 1992a, 1992b). The dataset contains both granted patents and unexamined patent applications which were published before 1988. Successful (granted) patent applications were selected and classified according to the three processes (mercury, diaphragm, and ion exchange membrane). The selected patents are arranged by the year of application, rather than by the year of publication. As information on the date of patent applications is not included in the data on the mercury process, a two-year lag was assumed between patent application and granting.

\section{Figure 3 about here}

As Figure 3 shows that most of the patents granted in the late 1960s were related to the mercury process. The number of successful patents on the mercury process rose at the beginning of the 1970s, as the general public's concern on mercury pollution increased. It then decreased subsequently, coinciding with the government decision that the mercurybased plants in the Japanese chlor-alkali industry were to be phased out rather immediately. Patents successfully applied on technologies related to the diaphragm process were few in the later 1960s and the early 1970s. They increased to some extent in the middle of the 1970s, as patent applications on the mercury process declined. Then, successful patent applications on the diaphragm process started to drop in the late 1970s, and it almost stopped by the middle of the 1980s. With regard to the ion exchange membrane process, although several patent applications already had been made in the late 1960s, most of the patents granted were on ion exchange membranes based on hydrocarbon polymers. These patented technologies were intended mainly for producing salt from seawater and the application of ion exchange membranes for use in chlor-alkali electrolytic cells was very limited. 
In the early 1970s, at the time of the government's decision to phase out the mercury process in Japan, applications for patents on ion exchange membranes started to rise. A patent application for a new type of ion exchange membranes based on fluorocarbon polymers marked the beginning of a period of rapid increase in successful patent applications on the ion exchange membrane process which lasted until 1980. The number of patents then declined in the 1980s but remained higher than the number of patents on the mercury or diaphragm processes.

The analysis in this study focused on the Japanese firms which had been innovative on the mercury process, namely, Mitsui Engineering and Shipbuilding, Osaka Soda, Kureha Chemical Industry, Asahi Glass, Toyo Soda, Tokuyama Soda, and Asahi Chemical Industry, and those companies which had been innovative on the diaphragm process, namely, Nippon Soda, Tsurumi Soda, and Showa Denko (Yarime 2003). Detailed analysis of patents shows that Asahi Chemical Industry, Asahi Glass, and Tokuyama Soda also applied successfully for many patents on the ion exchange membrane process. The three companies had earlier experiences of developing and utilizing ion exchange membranes. In trying to develop a new efficient process for salt production from seawater, the three Japanese companies had started to conduct R\&D activities on ion exchange membranes in the 1960s. As ion exchange membranes were initially based on hydrocarbons, however, they could not maintain their chemical stability in a strong alkaline environment and hence not readily usable for chlor-alkali production. Although the idea of using ion exchange membranes for electrolytic chlor-alkali production had existed since the 1950s, a complete lack of suitable ion exchange membranes prevented industrial realization and commercialization of the ion exchange membrane process.

In the early 1970s a new type of ion exchange membranes (Nafion) was released by Du Pont and made available to the Japanese chlor-alkali industry. The availability of Nafion contributed to further innovation in ion exchange membranes and their application to the chlor-alkali production. Almost in the same period, the government made the decision to phase out all the mercury-based plants in Japan. This policy created demand for clean technologies to replace the mercury process and, in particular, provided a significant impetus for those companies which had expertise on ion exchange membranes to intensify research efforts to develop the ion exchange membrane process for chlor-alkali production. While the government did not directly give any financial support to their $\mathrm{R} \& \mathrm{D}$ activities in the ion exchange membrane process, that policy worked to assure them that there would be large, secured the demand for alternative processes and thus encouraged innovative companies to invigorate R\&D efforts for developing the ion exchange membrane process.

The patent analysis also revealed that Mitsui Engineering and Shipbuilding, Kureha Chemical Industry, and Osaka Soda, which had been innovative in the mercury process, did not make successful patent applications on technologies related to the ion exchange membrane process. Mitsui Engineering and Shipbuilding, through establishing an engineering company, Chlorine Engineers Corp. (CEC), immediately after the phase-out decision, focused on cleaning techniques to eliminate mercury from the production process. Without sufficient experience in the ion exchange membrane process, CEC 
chose the diaphragm process for their technological target and decided to introduce technologies from foreign companies, particularly those in the United States. Similarly, Kureha Chemical Industry chose the diaphragm process as its R\&D target, following the government decision on the phase out of the mercury process. The company succeeded in developing a diaphragm-based electrolytic cell, used later to convert one of its own mercury-based plant. Although the patent data suggests that R\&D activities were conducted later in the 1970s, Kureha Chemical Industry did not develop its own technologies for the ion exchange membrane process until much later. Osaka Soda focused R\&D efforts on the diaphragm process, following the earlier government policy.

As discussed earlier, the diaphragm process turned out to be inappropriate for producing high-quality caustic soda. In the meantime, having seen a rapid progress in developing new types of ion exchange membranes by Asahi Chemical Industry, Asahi Glass, Tokuyama Soda, and Asahi Chemical Industry took advantage of the government decision to phase out the mercury process by cooperating with several chlor-alkali producers in R\&D activities on electrolytic cells designed for use in the ion exchange membrane process.

\section{Regulatory Change and Diffusion of the Ion Exchange Membrane Process}

The rapid progress in the technological performance of the ion exchange membrane process prompted the government to establish an expert group for a technical evaluation of the emerging process. The Expert Committee for Technical Evaluation of the Ion Exchange Membrane Process (Evaluation Committee) set out to do its assigned task in June 1977, with all of its four members coming from academic institutes (Expert Committee for Technical Evaluation of the Ion Exchange Membrane Process, 1977). This selection of the members was intended to help the committee conduct technological evaluation from a neutral position, avoiding intervention of particular industrial or corporate interests. The Evaluation Committee made a thorough examination of several technologies which were being developed at that time by chlor-alkali companies, domestic as well as foreign, through documents, interviews, and, in some cases, visits to plant sites. Various aspects were scrutinized, ranging from technical performance such as power consumption, product quality, durability and stability, environmental and safety measures, construction, and operational costs.

In October 1977, the Evaluation Committee acknowledged that the ion exchange membrane process technology had reached a level appropriate for industrialization but called for a more cautious approach to the evaluation of the new process, taking into full account the importance of caustic soda and chlorine as basic chemical materials and thus their impact on other industries. The Committee stated that the viability of the new technology must be demonstrated through the durability of various materials and the operational performance of plants. Since there were not sufficient data on these aspects at the time, the Committee members thought it necessary to continue their observation to obtain more data on the operation of commercial plants for at least two years (Expert Committee for Technical Evaluation of the Ion Exchange Membrane Process, 1977). 
Based on these findings, the government decided to interrupt the implementation of the process conversion program for two years. In September 1978, almost one year after the publication of the first report, the members of the Evaluation Committee resumed their activities to see the technological progress made during the past year. Their investigation revealed that, as several companies actively conducted $\mathrm{R} \& \mathrm{D}$ activities, considerable progress had been made on the ion exchange membrane process. Asahi Chemical Industry's first commercial plant and Asahi Glass's demonstration plant had already had experiences of stable operation for several years. Tokuyama Soda had also started to operate commercial plants using ion exchange membranes without encountering serious problems. These examples of stable and reliable plant operation convinced the members of the Evaluation Committee that the ion exchange membrane process not only eliminated mercury emissions into the environment, but also had surpassed the mercury process in the efficiency of energy consumption while producing caustic soda with the same quality as the mercury process. Taking into account the operating experiences of various plants overall, the Evaluation Committee concluded that the ion exchange membrane process in Japan had reached a level to become the established industrial technology (Expert Committee for Technical Evaluation of the Ion Exchange Membrane Process, 1979).

Prompted by the final conclusion, the Countermeasures Council started to review the regulatory schedule which had been initially fixed in a rigid, short-term framework. At its fifth meeting held in September 1979, the Countermeasures Council reached an agreement that the remaining mercury process plants were to be converted by the end of 1984 (Council for the Promotion of Countermeasures against Mercury Pollution, 1979). This extension of the deadline for process conversion was intended to enable the operators of mercury-based plants to adopt the more efficient ion exchange membrane process, instead of the diaphragm process, in the second phase of the process conversion program. Still, some manufacturers that had heavily depended on the mercury process argued that they needed more time to see whether the newly developed ion exchange membrane process was economically viable (Katsumura 1979, Japan Soda Industry Association 1980b), the Countermeasures Council did not change its revised schedule for the completion of process conversions at subsequent meetings (Council for the Promotion of Countermeasures against Mercury Pollution, 1980, 1981, 1982).

Immediately after the decision to phase out the mercury process, the spread of the diaphragm process increased rapidly and reached its peak in the middle of the 1970s. While the provision of the diaphragm process then declined quickly and ceased in 1980 while the ion exchange membrane process emerged in the mid-1970s and showed a large increase in the 1980s. The use of the ion exchange membrane process declined in the late 1980s, following the completion of the process conversion program in Japan, but picked up again in the 1990s. In particular, Asahi Chemical Industry, Asahi Glass, Tokuyama Soda, which had accumulated experience in testing new technologies at their own chloralkali production plants during the second half of the 1970s, started to provide their technologies to other chlor-alkali producers in Japan in the 1980s (Asahi Chemical Industry 1998, Asahi Glass 1999, Tokuyama 2002). CEC, on the other hand, introduced technologies for the diaphragm process from abroad and began to supply them to chlor- 
alkali producers in Japan immediately after the government policy for the phase out of the mercury process (Chlorine Engineers Corp. 1999b).

By 1977, when the initial schedule of the conversion program was reviewed, CEC's diaphragm process had been adopted by many chlor-alkali producers in Japan. As the diaphragm process turned out to be an inappropriate technology, CEC started to supply ion exchange membrane process technologies to chlor-alkali producers at the beginning of the 1980s (Chlorine Engineers Corp. 1999a, 1999c, 2000). In the mid 1980s, as the deadline for complete abolishment of the mercury process approached, these four companies provided the ion exchange membrane technologies to many Japanese chloralkali producers who had to convert their mercury-based plants. In the late 1980s, having finished supplying domestic chlor-alkali producers with their ion exchange membrane process technologies, these companies started to actively seek customers abroad, particularly those in other countries in Asia such as Taiwan, South Korea, and China.

The overall trends in Japanese production capacities based on the mercury process, the diaphragm process, and the ion exchange membrane process from the early 1970s are shown in Figure 4.

\section{Figure 4 about here}

Following the phase-out regulation in 1973 most of the mercury process plants were converted to the diaphragm process because at the time the diaphragm process was less energy intensive than the emerging ion exchange membrane process. This difference in energy consumption made the diaphragm process more economically viable. The share of the diaphragm process jumped to more than $60 \%$ in just seven years while the mercury process dropped rapidly. During the same period (early- to mid-1970s) the production cost of the diaphragm process was increasing due to rapid rises in energy prices following the oil crisis. In addition, there was serious concern about the low quality of product being produced by the converted chlor-alkali plants.

In the second half of the 1970s, the technologically improved ion exchange membrane process was initially installed at chlor-alkali plants by the first movers which had developed the technologies by themselves. Although at that time the technological performance of the ion exchange membrane process was not economically viable, the impetus of the phase-out regulation had forced some industry actors to invest further in developing the ion exchange membrane process. With reports of successful trials by the first-mover companies other chlor-alkali producers gradually started to introduce the ion exchange membrane process in the early 1980s, replacing the mercury process (and later the diaphragm process). Most of the introductions of the ion exchange membrane process subsequently took place in just a few years before the extended deadline. The last chloralkali plant based on the mercury process was finally converted at the end of June in 1986, 13 years after the government's initial decision to eliminate the mercury process in the Japanese chlor-alkali industry. When the mercury process was completely abolished, the installed capacity of the ion exchange membrane process accounted for a little more 
than half of the total production capacity with the other half having adopted the diaphragm process. Since then, the share of the ion exchange membrane process has increased steadily, reaching more than $95 \%$ in 1999.

Figure 4 shows the operating period of the chlor-alkali plants which had adopted the diaphragm process in Japan. The figure indicates that all of the chlor-alkali plants which had been converted to the diaphragm process following the phase-out regulation were converted again to the ion exchange membrane process. The operating period of the diaphragm plants was very short, averaging at 10 years, which is far shorter than the normal period of plant operation of approximately 40 years in the chemical industry (Society of Chemical Engineers of Japan, 1998). Assuming that the investment cost for the construction of a plant remained the same between the diaphragm process and the ion exchange membrane process, more than $90 \%$ of the investment of 231.8 billion yen which was spent in the first phase of the conversion program was used to introduce the diaphragm process, soon to be scrapped in favour of the ion exchange membrane process.

The financial resources allocated by the chlor-alkali industry to the conversion programme constituted a considerable burden on an industry which had already been severely hit by the rise in energy prices due to the oil crisis of the early 1970s. The sum of the industry's annual turnover in the first phase of the conversion program from 1973 to 1977 was 630.9 billion yen (Japanese Ministry of International Trade and Industry 1985). The amount of financial resources devoted to convert mercury-based plants to diaphragm-based plants, which were to be converted again to the ion exchange membrane process in a very short period of time, reached more than one third of the industry's turnover in the same period. This clearly indicates that the investment necessary for process conversion had a significant impact on the financial standing of the Japanese chlor-alkali industry as a whole. In retrospect, significant conversion costs could have been avoided had the mercury-based plants been converted directly to the ion exchange membrane process, without going through the diaphragm process. To realize that route of technological change, however, a different regulatory schedule for the elimination of the mercury process would have been necessary, an unrealistic option given the severity of the Minamata disease outbreak. It was necessary for the government to step in and minimize the damage through the best available means at the time.

\section{Transition(s) in the Japanese Chlor-Alkali Industry and Institutions}

Applying the concept of transitions and transition management to the Japanese chloralkali industry, two main interpretations of the events emerge. First, we can view the replacement of the mercury process by the diaphragm process as a short-lived transition to a new, albeit inferior, technological regime. This interpretation may be substantiated by the stability of the diaphragm process during the 1975-1985 period as indicated in Figure 4. During this period $60 \%$ of the chlor-alkali sector used the diaphragm process as its production technology. According to this first interpretation the transition to the diaphragm processes was in turn superseded by a second transition to the ion exchange membrane process. The primary drivers of the two transitions are shown in Figure 5A. 


\section{Figure 5A about here}

A second interpretation, and one we subscribe to, holds that a combination of endogenous (high costs and inferior product quality) and exogenous (the energy crisis and the emergence of the ion exchange membrane technology) prevented the diaphragm process from becoming fully instituted within the sector. A transition from the mercury process to the diaphragm process may thus be interpreted as unsuccessful (Figure 5B).

\section{Figure 5B about here}

Using either of these two interpretations, we can highlight the main institutions and the catalysts for the institutionalization processes that facilitated the shift(s) in the technological regime. Arguably, "the way the game was being played" changed with the discovery of Minamata disease. At the time of the outbreak methods for the disposal of industrial effluents in Japan were organized through long-established routines, habits, and beliefs (beharvioural institutions) based on there being no environmental or health consequences in releasing untreated effluent into the environment. With the discovery of Minamata disease, a new "mental model" (cognitive institution) emerged that questioned the conventional wisdom of releasing untreated industrial effluent into the environment and called for a closed loop system that prevented all such releases. However, it would be some time before the new mental model was adopted. Further, the new mental model would require government intervention (through constitutive and regulative institutions) to become firmly established.

Government intervention was executed through a series of guidelines, consultative agreements, the setting up of formal government and non-government agencies (e.g., the Conversion Committee established in 1973), provision of tax incentives and technical expertise, and regulations all of which fit into the category of regulative institutions in the typology of institutions (Table 1). The best example of an associative institution in this case study is the chlor-alkali industry association and its lobbying role of the government decision makers throughout the transition process. A number of the coalitions and organizations that were initiated by the government, such as the Conversion Committee and the Countermeasure Council, also fit into the category of associative institutions since they encompassed an extensive range of actor interests including banks, academia, the media, and industry. The Ministry of International Trade and Industry (MITI) and the Environmental Agency played dual roles as both regulative and constitutive institutions since each of these agencies set "the bounds of social relations" and actively regulated through continually defining and redefining "the rules of the game”.

\section{Conclusion}

There has been ongoing debate on the effects of environmental regulation on innovation and industrial competitiveness. On the one hand, environmental regulations are said to increase production costs, hamper productivity, and thereby hinder the ability of companies to compete in international markets. Regulated firms are forced to devote resources to pollution abatement and control without increasing output. This was 
certainly the case with the Japanese experience, particularly in attempts to effect a transition from the mercury to the diaphragm process. On the other hand, according to the Porter hypothesis, stringent environmental regulations can actually enhance the competitive position of firms by encouraging them to undertake more research in developing environmentally benign technologies. Ownership of new environmental technologies allows the inventing firms to exploit new market opportunities. This second position also holds true in the Japanese experience: the firms that invested in further development of the ion exchange membrane technologies became the suppliers of the new technologies to firms in Taiwan, South Korea, and China.

The Japanese experience is unique in highlighting the role of institutions in the interplay between government and firms. We have indicated that transitions as products of government intervention are facilitated through a range of formal and informal institutions (the typology in Table 1). Awareness of these institutions, their role in facilitating and curtailing technological transitions, and the need for the modification of current institutions or initiating new institutions to ensure moving along a desired technological trajectory are crucial components of "interactive” or "deliberative” policy making. ${ }^{9}$ The Japanese experience offers numerous examples of policy learning of the type described by Hajer (2003). In the first instance the government maintained a rigid but justified position on the elimination of the mercury process. This position forced the chlor-alkali industry to largely imitate rather than develop a new technology. The adoption of the diaphragm process was costly and produced inferior quality product. Various measures were taken by the government in response to the industry's demands for a level playing field and to provide an opportunity for the diaphragm process to become fully instituted. Despite the inferiority of the selected technology the measures were successful and $60 \%$ of the firms switched to the diaphragm process.

The government-sponsored diaphragm process weakened the competitive position of the Japanese chlor-alkali industry. Acting very much in tune Hajer's (2003) notions of deliberative and interactive policymaking the government kept fully informed of the impact of the diaphragm process on the industry. The inclusion of a multiplicity of interests and expertise in the decision making process kept the government attuned to: a) the industry's concerns about the necessary technological shift and, b) the latest technological developments including the emergence of the ion exchange membrane process. One important aspect of the learning processe by the policy makers was that the adoption of ion exchange membrane processes was not dictated to the industry, as the diaphragm process had been. Instead, the government decision making bodies proceeded cautiously until there was sufficient evidence that the ion exchange membrane process was indeed economically viable and produced a comparable or superior product to that from the mercury or the diaphragm processes.

We must not lose sight of the fact, however, that the phase-out policy and regulations created a large, secured demand for mercury-free cleaner production type technologies.

\footnotetext{
${ }^{9}$ Hajer (2003:191) defines deliberative policy making as "a varied search for understandings of society to facilitate meaningful and legitimate political actions, agreed upon in mutual interaction, to improve our collective quality of life".
} 
As the regulatory schedule for the conversion of the mercury process was initially set with a rigid, short-term deadline, most of the chlor-alkali manufacturers had no choice other than to adopt the diaphragm process, which had been long in use in the industry in other countries. While there were cost and quality disadvantages associated with the diaphragm process, the phase-out policy also set the stage for work on radically new clean technologies. Companies with expertise and experiences in developing ion exchange membranes from other industries seized on this opportunity and innovated to improve the still infant ion exchange membrane process for chlor-alkali production.

Through the technical assessment of the ion exchange membrane process by the expert committee the government modified the original schedule for process conversion and postponed the deadline for the complete elimination of the mercury process. This adjustment of the regulatory schedule allowed more time for the innovative companies to intensify $R \& D$ activities on the ion exchange membrane process and to learn through testing the technology at chlor-alkali plants, promoting further progress in the promising technology. The ion exchange membrane process advanced to become the best technology. Currently the vast majority of chlor-alkali plants use the ion exchange membrane process while the technology is increasingly being adopted by chlor-alkali producers in other countries. Subsequent incremental improvements of the ion exchange membrane process technology improved energy efficiency and made it economical even compared to the mercury process.

The mercury-based plants which had been converted to the diaphragm process immediately following the policy of eliminating the mercury process were later converted again to the ion exchange membrane process. The operating period of these plants based on the diaphragm process turned out to be significantly shorter than that of plants operated in normal conditions, and thus constituted a disproportionate loss of investment to the converted plants. Although the rigid regulatory schedule was modified subsequently, the (attempted) management of the technological transition was at first unsuccessful and turned out to be very costly. The stringent but necessary policy of immediately abandoning the existing mercury process undermined the competitive position of the firms.

This case demonstrates that managing transitions to deal with acute environmental and health problems requires stringent but long-term policy and regulations. A long term perspective allows firms (and the government) to experiment, learn, and innovate rather than merely imitate. Transition management entails flexibility in the regulatory approach, interaction with as many stakeholders as possible, and deliberation to take full advantage of collective learning. In the Japanese case there is strong evidence of learning by the government and other stakeholders. A number of formal institutions were set up to capture the feedback from the industry and to facilitate knowledge accumulation on and the dissemination of the best available and the most promising technologies. This case also demonstrates that firms are more likely to invest in cleaner technologies if they have confidence, as signaled by regulatory direction, in the emergence of new markets for such technologies. 
Figure 1. Phases of Transitions

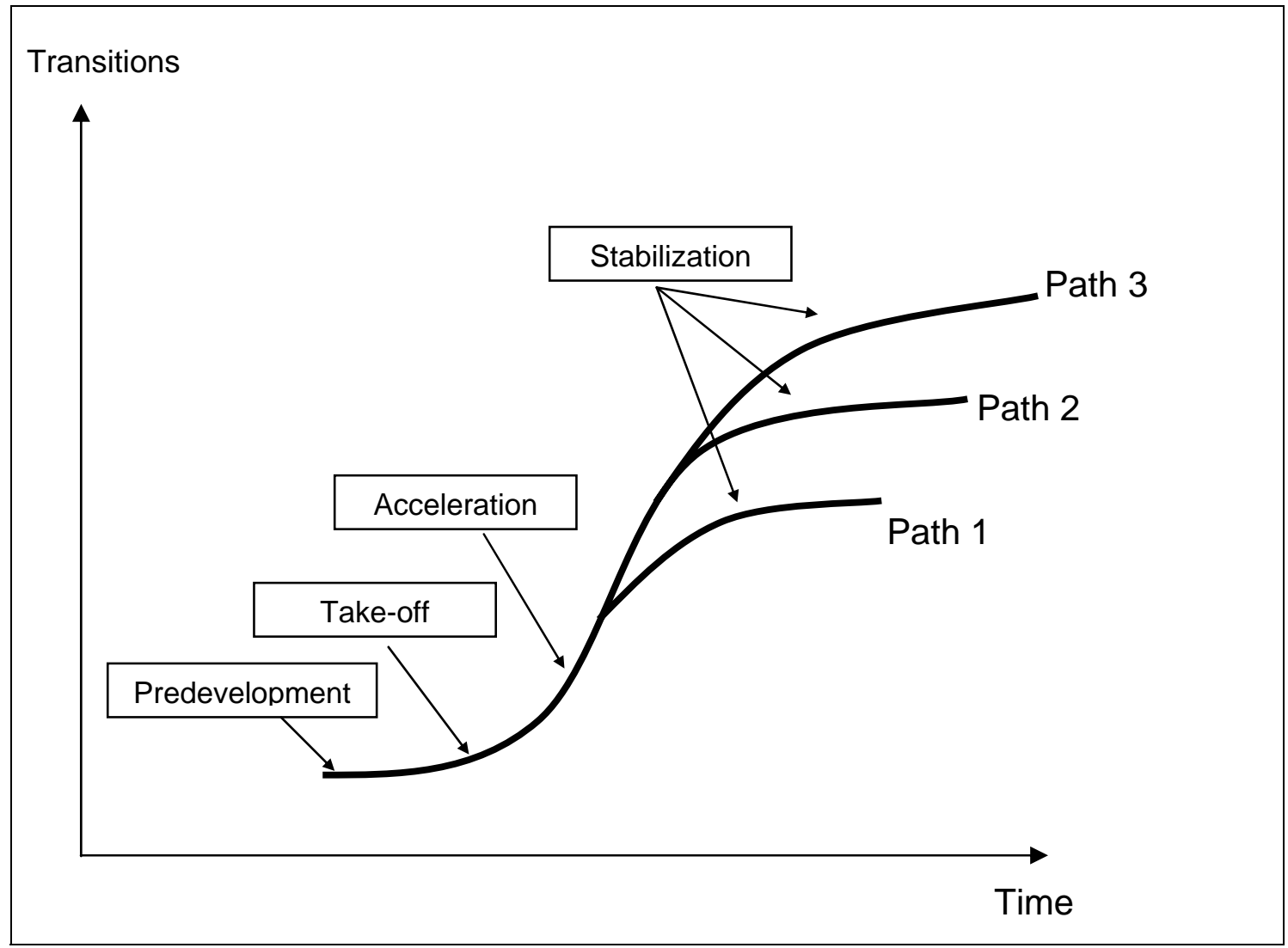

Adapted from Rotmans, Kemp, and van Asselt (2001)

Table 1. Types of Institution

\begin{tabular}{|l|l|}
\hline Institution Type & Examples / Catalysts* \\
\hline $\begin{array}{l}\text { Behavioural: Institutions as standardized } \\
\text { (recognizable) social habits - manifested in } \\
\text { activities of individuals and groups as reflections } \\
\text { of social norms }\end{array}$ & $\begin{array}{l}\text { Habits; Routines; Artefacts; Ways of Doing } \\
\text { Things; Shared Beliefs; Theories in Use; “How the } \\
\text { Game is Played” }\end{array}$ \\
\hline $\begin{array}{l}\text { Cognitive: Institutions as mental models and } \\
\text { constructs or definitions - manifested primarily in } \\
\text { what society expects of individuals }\end{array}$ & $\begin{array}{l}\text { Cultural and Social Values; Superstitions; } \\
\text { "Wisdom”; “How the Game Ought to be Played” }\end{array}$ \\
\hline $\begin{array}{l}\text { Associative: Institutions as mechanisms } \\
\text { facilitating prescribed or privileged interaction } \\
\text { among different private and public interests }\end{array}$ & $\begin{array}{l}\text { Business Networks; Kinship Groups; Social } \\
\text { Classes; Associations; Interest Groups }\end{array}$ \\
\hline $\begin{array}{l}\text { Regulative: Institutions as prescriptions and } \\
\text { proscriptions }\end{array}$ & $\begin{array}{l}\text { Written and Unwritten “Rules of the Game”; State } \\
\text { as Rule Maker, Referee, and Enforcer }\end{array}$ \\
\hline $\begin{array}{l}\text { Constitutive: Institutions setting the bounds of } \\
\text { social relations }\end{array}$ & $\begin{array}{l}\text { Collective Actions initiated by the State Agencies, } \\
\text { Firms, Unions, or Citizens Groups; Language; } \\
\text { Property Rights Structures; Agreements; } \\
\text { Arrangements; Marriage; Family }\end{array}$ \\
\hline $\begin{array}{l}\text { * An institution is the product of an institutionalization process set in motion by an “event”, or group of } \\
\text { events. The examples cited here are viewed as being capable of instituting new and modifying (or } \\
\text { augmenting) current norms, forms, and routines. }\end{array}$ \\
\hline
\end{tabular}
Source: Parto (2005) 
Figure 2. Shares of the Mercury, Diaphragm, and Ion Exchange Membrane Processes in Western Europe, the United States, and Japan in 1998

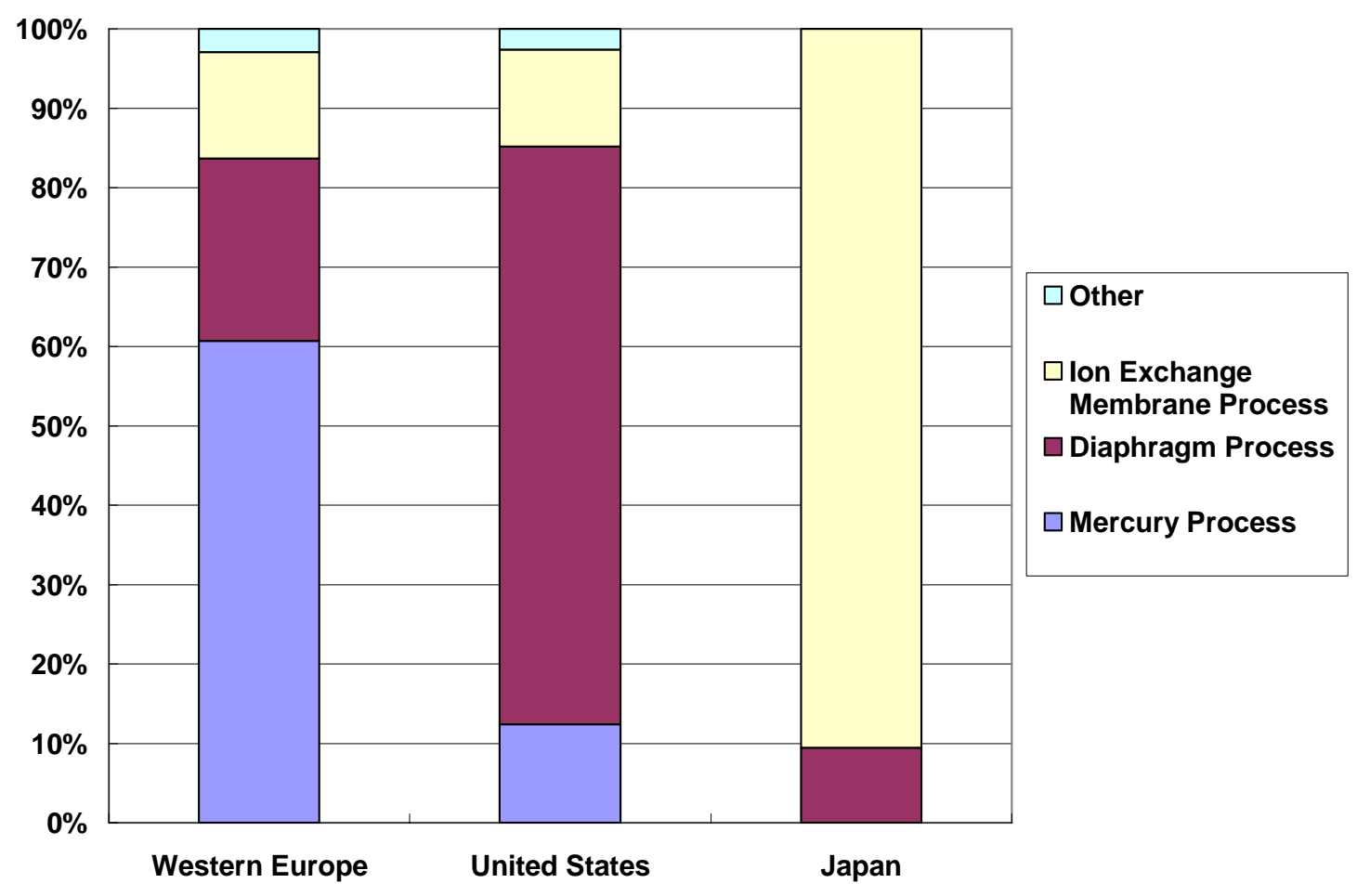


Figure 3. Japanese Patents Successfully Applied for by Japanese Firms on the Mercury, Diaphragm, and Ion Exchange Membrane Processes

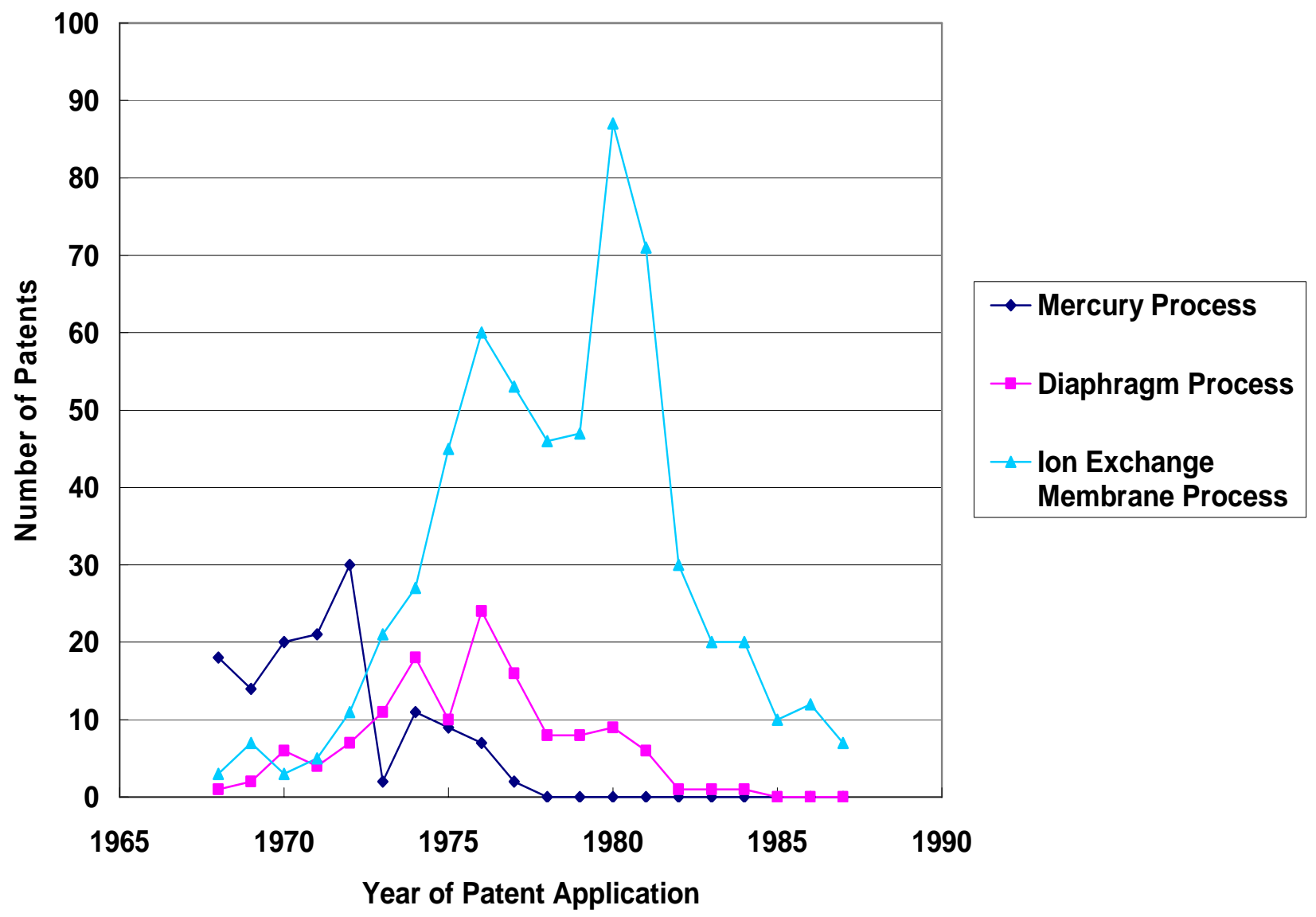


Figure 4. Production Capacities of the Mercury, Diaphragm, and Ion Exchange Membrane Processes in the Japanese Chlor-Alkali Industry

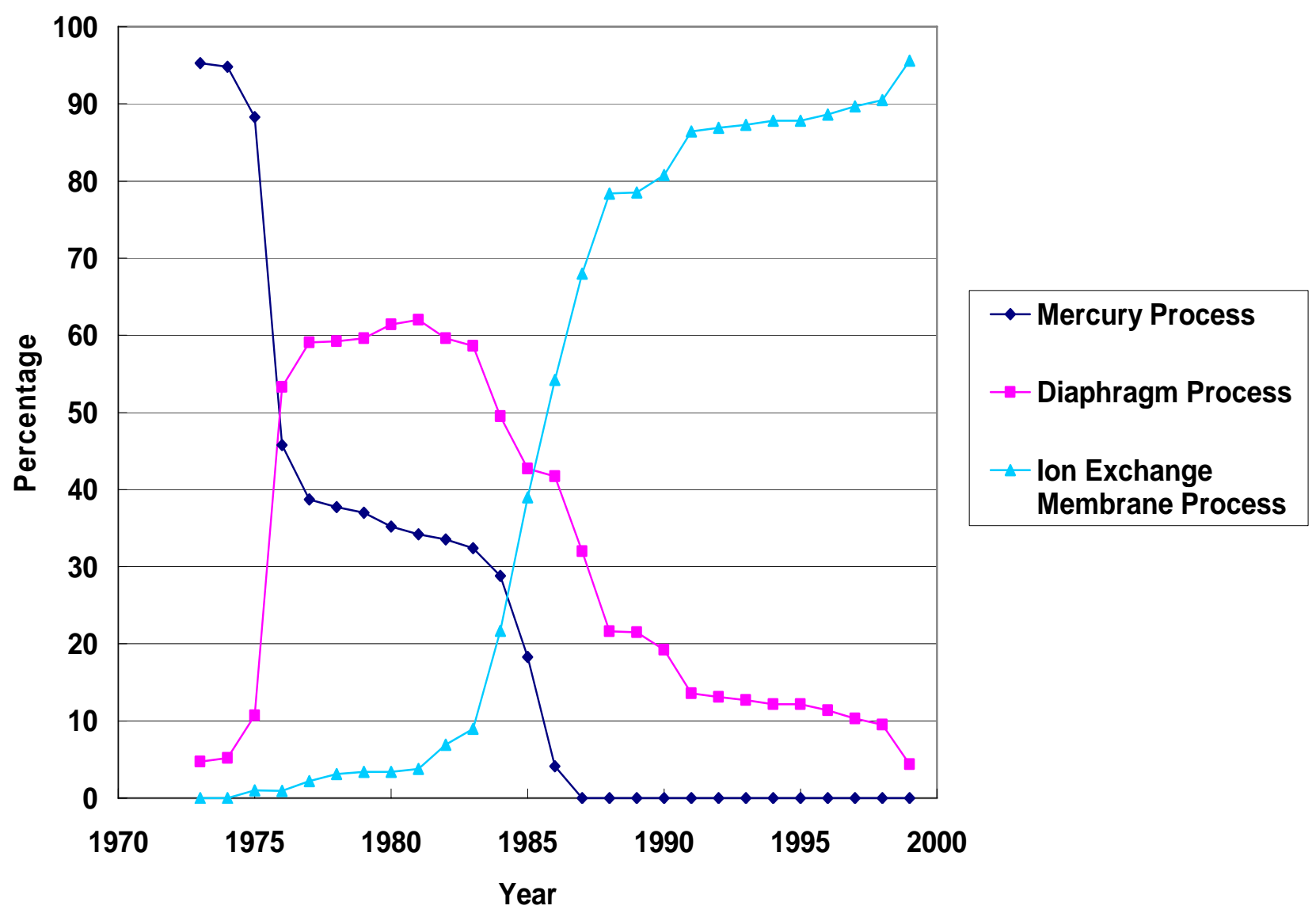


Figure 5A. Primary Drivers of Technological Change in the Japanese Chlor-Alkali Industry

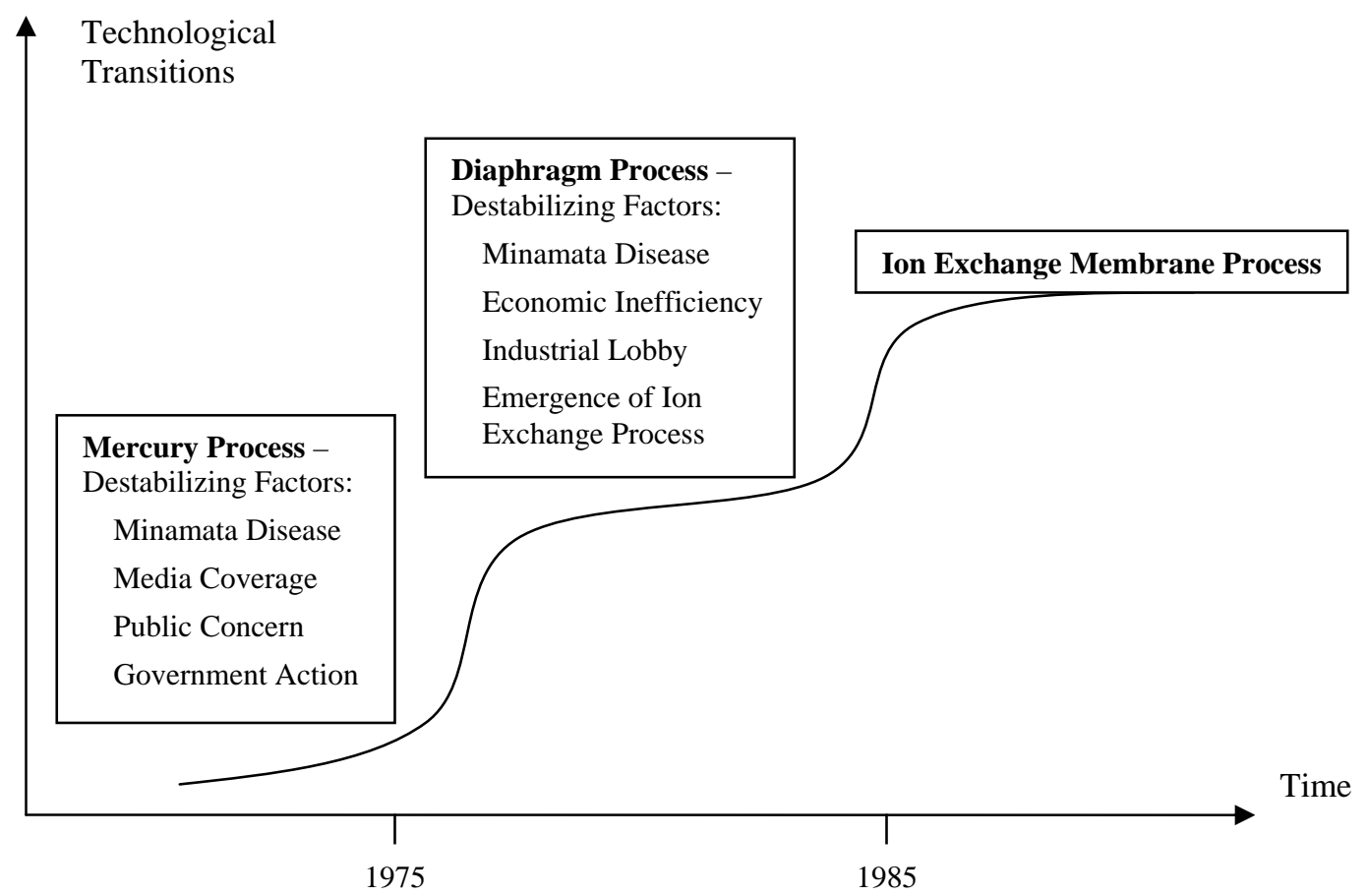


Figure 5B. Technological Transition in the Japanese Chlor-Alkali Industry

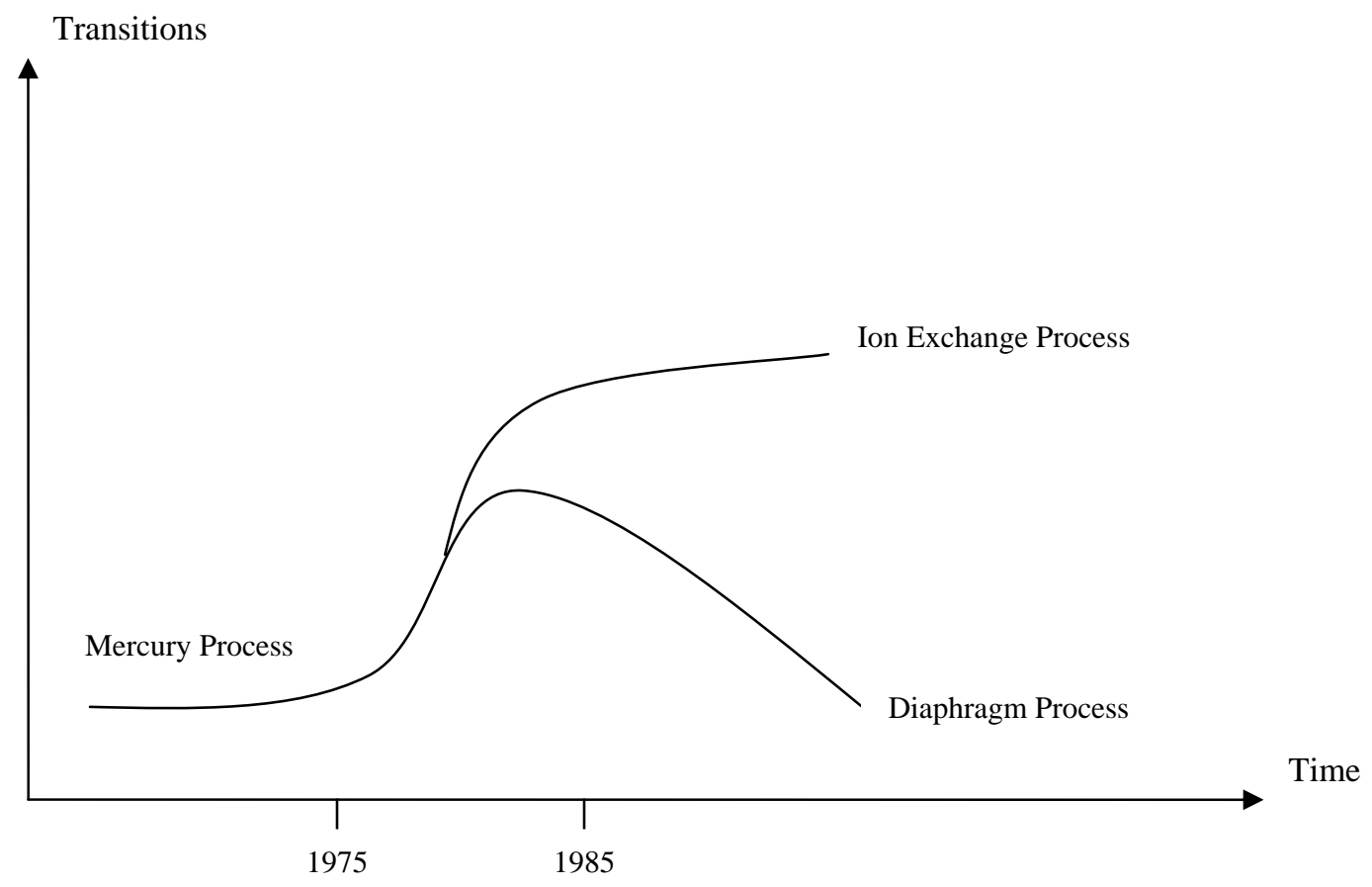




\section{References}

Asahi Chemical Industry (1998). "Chlor-Alkali Plant Capacity Employing Asahi Chemical Bipolar Process." Asahi Chemical Industry. January.

Asahi Glass (1999). "AZEC Electrolyzer Supply Record." Asahi Glass. August.

Asahi Shinbun (1973a). "Ariake-kai ni 'Daisan Minamata-byo' ('The Third Minamata Disease' in the Ariake Sea)." Asahi Shinbun. May 22.

Asahi Shinbun (1973b). "Tokuyama-wan Engan, Jumin ni Minamata-byo no Utagai (An Allegation of the Minamata Disease in the Tokuyama Bay area)." Asahi Shinbun. June 11.

Chlorine Engineers Corp. (1999a). "CME Supply Record." Chlorine Engineers Corp.

Chlorine Engineers Corp. (1999b). "Diaphragm Cell Supply Record." Chlorine Engineers Corp.

Chlorine Engineers Corp. (1999c). "MBC Supply Record." Chlorine Engineers Corp.

Chlorine Engineers Corp. (2000). "Supply Record of CEC's IEM Electrolyzer." Chlorine Engineers Corp. January.

Council for the Promotion of Countermeasures against Mercury Pollution (1973). "Dai 3-kai Suiginto Osen Taisaku Suishin Kaigi Giji Yoshi (Abstract of the Note of the 3rd Meeting of the Council for the Promotion of Countermeasures against Mercury Pollution)." Council for the Promotion of Countermeasures against Mercury Pollution. November 10.

Council for the Promotion of Countermeasures against Mercury Pollution (1977). "Dai 4-kai Suiginto Osen Taisaku Suishin Kaigi Kettei (Decisions of the 4th Meeting of the Council for the Promotion of Countermeasures against Mercury Pollution)." Council for the Promotion of Countermeasures against Mercury Pollution. May 25.

Council for the Promotion of Countermeasures against Mercury Pollution (1979). "Dai 5-kai Suiginto Osen Taisaku Suishin Kaigi Kettei (Decisions of the 5th Meeting of the Council for the Promotion of Countermeasures against Mercury Pollution)." Council for the Promotion of Countermeasures against Mercury Pollution. September 17.

Council for the Promotion of Countermeasures against Mercury Pollution (1980). "Dai 6-kai Suiginto Osen Taisaku Suishin Kaigi Kettei (Decisions of the 6th Meeting of the Council for the Promotion of Countermeasures against Mercury Pollution)." Council for the Promotion of Countermeasures against Mercury Pollution. September 22.

Council for the Promotion of Countermeasures against Mercury Pollution (1981). "Dai 7-kai Suiginto Osen Taisaku Suishin Kaigi ni tsuite (On the 7th Meeting of the Council for the Promotion of Countermeasures against Mercury Pollution)." Council for the Promotion of Countermeasures against Mercury Pollution. December 18.

Council for the Promotion of Countermeasures against Mercury Pollution (1982). "Dai 8-kai Suigin-to Osen Taisaku Suishin Kaigi ni tsuite (On the 8th Meeting of the Council for the Promotion of Countermeasures against Mercury Pollution)." Council for the Promotion of Countermeasures against Mercury Pollution. November 26.

Davis, K. (1945), The world demographic transition”, Annals of the American Academy of Political and Social Science 237 (4): 1-11

European Chemical News (1974). Electrolytic Chlor-Alkali Plants in Japan Licensed by Hooker. European Chemical News.

Expert Committee for Technical Evaluation of the Ion Exchange Membrane Process (1977). "Ion Kokanmaku-ho Gijutsu Hyoka Kekka (Results of Technical Evaluation of the Ion Exchange Membrane Process)." Committee for the Promotion of Process Conversions in the Soda Industry. October 25.

Expert Committee for Technical Evaluation of the Ion Exchange Membrane Process (1979). "Ion Kokanmaku-ho Gijutsu Hyoka Kekka (Results of the Technical Evaluation of the Ion Exchange Membrane Process)." Committee for the Promotion of Process Conversions in the Soda Industry. June 13. 
Gersick, C. J. G. (1991) "Revolutionary Change theories: A multilevel Exploration of the Punctuated Equilibrium Paradigm”. The Academy of Management Review, 16:1, 10-36.

Hajer, M. (2003). "Policy without polity? Policy analysis and the institutional void”. Policy Sciences 36: 175-195.

Irukayama, Katsuro (1977). "Countermeasures and Unresolved Problems," in T. Tsubaki and K. Irukayama, eds. Minamata Disease: Methylmercury Poisoning in Minamata and Niigata, Japan. Tokyo: Kodansha.

Jaffe, Adam B., Steven R. Peterson, Paul R. Portney, and Robert N. Stavins (1995). "Environmental Regulation and the Competitiveness of U.S. Manufacturing: What Does the Evidence Tell Us?" Journal of Economic Literature, 33, 132-163.

Japan Soda Industry Association (1973a). "Denkai Soda Kogyo no Jitsujo (Real Situation of the Electrolytic Soda Industry)." Statement. Japan Soda Industry Association. June 27.

Japan Soda Industry Association (1973b). "Request to the Minister of the Environmental Agency Regarding the Real Situation of the Soda Industry." Japan Soda Industry Association. July 11.

Japan Soda Industry Association (1974). "Seiho Tenkan ni kansuru Sho-Mondai ni tsuite (Various Issues on the Process Conversion)." Soda to Enso, (2), 1-13.

Japan Soda Industry Association (1975). Soda Handobukku (Soda Handbook). Tokyo: Japan Soda Industry Association.

Japan Soda Industry Association (1976). "Tokkyo kara mita Shokuen Denkai ni okeru Kinzoku Yokyoku/Ion Kokanmaku-ho Kanren Gijutsu no Genjo, Bessatsu 2: Tokkyo Gaiyo Ichiran-hyo (Current Situation of Technologies Related to the Metal Electrode and the Ion Exchange Membrane Process for Brine Electrolysis In Terms of Patents, Supplement Volume 2: Lists of Patent Abstracts)." Technology Examination Document. Japan Soda Industry Association. December.

Japan Soda Industry Association (1977). "Shokuen Denkai ni okeru Kinzoku Yokyoku/Ion Kokanmaku-ho Kanren Tokkyo no Genjo, Tsuiroku-ban I: Showa 57.7-12 Kokoku/Kokai-bun (Current Situation of Patents Related to the Metal Electrode and the Ion Exchange Membrane Process for Brine Electrolysis, Sequel Edition I: Publications from July 1976 to December 1976)." Technology Examination Document. Japan Soda Industry Association. September.

Japan Soda Industry Association (1978a). "Shokuen Denkai ni okeru Ion Kokanmaku-ho narabini Kakumaku-ho Kanren Tokkyo no Genjo, Tsuiroku-ban III: Showa 52.1-12 Kokoku, Kokai-bun (Current Situation of Patents Related to the Ion Exchange Membrane Process and the Diaphragm Process for Brine Electrolysis, Sequel Edition III: Publications from January 1977 to December 1977)." Technology Examination Document. Japan Soda Industry Association. December.

Japan Soda Industry Association (1978b). "Shokuen Denkai ni okeru Kakumaku-ho Kanren Tokkyo no Genjo, Tsuiroku-ban II: Showa 30-51 nen Kokoku/Kokai-bun (Current Situation of Patents Related to the Diaphragm Process for Brine Electrolysis, Sequel Edition II: Publications from 1955 to 1976)." Technology Examination Document. Japan Soda Industry Association. April.

Japan Soda Industry Association (1979a). "Dai-2-ki Seiho Tenkan Shisaku ni taisuru Yobo (Request Regarding Policies for the Second Phase of the Process Conversion)." Japan Soda Industry Association. June 14.

Japan Soda Industry Association (1979b). "Shokuen Denkai ni okeru Ion Kokanmaku-ho narabini Kakumaku-ho Kanren Tokkyo no Genjo, Tsuiroku-ban V: Showa 53.1-12 Kokoku, Kokai-bun (Current Situation of Patents Related to the Ion Exchange Membrane Process and the Diaphragm Process for Brine Electrolysis, Sequel Edition V: Publications from January 1978 to December 1978)." Technology Examination Document. Japan Soda Industry Association. December.

Japan Soda Industry Association (1980a). "Dai-2-ki Seiho Tenkan Mondai no Shuhen (Around the Issue of the Second Phase of the Process Conversion)." Soda to Enso, (8), 17-29.

Japan Soda Industry Association (1980b). "Dai-2-ki Seiho Tenkan ni kansuru Yobosho (Request Regarding the Second Phase of the Process Conversion)." Japan Soda Industry Association. September 14. 
Japan Soda Industry Association (1982). Nihon Soda Kogyo Hyakunen-shi (Centennial History of the Japanese Soda Industry). Tokyo: Japan Soda Industry Association.

Japan Soda Industry Association (1985). "Soda Kogyo Kankei no Kinyu oyobi Zeisei Sochi ni tsuite (On the Financial and Tax Measures Related to the Soda Industry)." Soda to Enso, (1), 20-25.

Japan Soda Industry Association (1988). "Denryoku (Electric Power)." Soda to Enso, (5), 46-55.

Japan Soda Industry Association (1991a). "Shokuen Denkai ni okeru Ion Kokanmaku-ho Kanren

Tokkyo no Genjo, Tsuiroku-ban VI: Showa 54 - 63 nen Kokoku/Kokai-bun, Dai 1 Bunsatsu:

Denkai Hoho oyobi Kanren Gijutsu, C-1 Sotai Kozo (Current Situation of Patents Related to the

Ion Exchange Membrane Process for Brine Electrolysis, Sequel Edition VI: Publications from 1979 to 1988, Volume 1: Electrolytic Methods and Related Technologies, C-1 Cell Structure)."

Technology Examination Document. Japan Soda Industry Association. July.

Japan Soda Industry Association (1991b). "Shokuen Denkai ni okeru Ion Kokanmaku-ho Kanren

Tokkyo no Genjo, Tsuiroku-ban VI: Showa 54 - 63 nen Kokoku/Kokai-bun, Dai 2 Bunsatsu:

Denkai Hoho oyobi Kanren Gijutsu, C-2 Denkai Hoho, C-3 Sonota (Current Situation of Patents

Related to the Ion Exchange Membrane Process for Brine Electrolysis, Sequel Edition VI:

Publications from 1979 to 1988, Volume 2: Electrolytic Methods and Related Technologies, C-2

Electrolytic Methods, C-3 Other)." Technology Examination Document. Japan Soda Industry

Association. July.

Japan Soda Industry Association (1992a). "Shokuen Denkai ni okeru Ion Kokanmaku-ho Kanren

Tokkyo no Genjo, Tsuiroku-ban VI: Showa 54 - 63 nen Kokoku/Kokai-bun, Dai 3 Bunsatsu: Ion

Kokanmaku, M (Current Situation of Patents Related to the Ion Exchange Membrane Process for Brine Electrolysis, Sequel Edition VI: Publications from 1979 to 1988, Volume 3: Ion Exchange Membranes, M)." Technology Examination Document. Japan Soda Industry Association. July.

Japan Soda Industry Association (1992b). "Shokuen Denkai ni okeru Ion Kokanmaku-ho Kanren

Tokkyo no Genjo, Tsuiroku-ban VI: Showa 54 - 63 nen Kokoku/Kokai-bun, Dai 4 Bunsatsu:

Denkyoku (E), Ensui Seisei (B), Sono-ta (T) oyobi Kakumaku (D) (Current Situation of Patents

Related to the Ion Exchange Membrane Process for Brine Electrolysis, Sequel Edition VI:

Publications from 1979 to 1988, Volume 4: Electrodes (E), Brine Purification (B), Other (T), and

Diaphragms (D))." Technology Examination Document. Japan Soda Industry Association. July.

Japan Soda Industry Association (1998). "Denryoku (Electric Power)." Soda to Enso, (12), 42-48.

Japanese Ministry of International Trade and Industry (1973). "Soda Kogyo ni okeru Suigin-ho kara

Kakumaku-ho eno Tenkan Kijun (Criteria for the Conversion from the Mercury Process to the

Diaphragm Process in the Soda Industry)." Ministry of International Trade and Industry.

November 19.

Japanese Ministry of International Trade and Industry (1975). "Kasei Soda Yuzu Jisshi Yoko

(Outline for the Implementation of Barter Trades of Caustic Soda)." Division of Basic Chemicals,

Bureau of Basic Industries, Ministry of International Trade and Industry. June 9.

Japanese Ministry of International Trade and Industry (1979). "Kasei Soda Kogyo Seiho Tenkan

Kankei Shiryo (Documents on Process Conversions in the Caustic Soda Industry)." Division of

Basic Chemicals, Bureau of Basic Industries, Ministry of International Trade and Industry. May.

Japanese Ministry of International Trade and Industry (1985). "Kasei Soda Kogyo no Genjo (Current

Situation of the Caustic Soda Industry)." Division of Basic Chemicals, Bureau of Basic Industries, Ministry of International Trade and Industry. November.

Japanese Ministry of International Trade and Industry (1989). "Soda Kogyo no Genjo to Kadai (Current Situation and Problems in the Soda Industry)." Division of Basic Chemicals, Bureau of Basic Industries, Ministry of International Trade and Industry. August.

Kanto Denka Kogyo (1998). Kanto Denka Kogyo Rokuju-Nenshi (Sixty-Year History of Kanto Denka Kogyo). Toyo: Kanto Denka Kogyo.

Katsumura, Tatsuo (1979). Soda Seiho Tenkan o Isoguna (Do not rush into process conversions for the soda production). Asahi Shinbun 
Kay, J.J. (1991). “A Non-equilibrium Thermodynamic Framework for Discussing Ecosystem Integrity”, Environmental Management, 15 (4): 483-495.

Kingdon, J. (1984[1995]). Agendas, Alternatives, and Public Policies (Boston: Little, Brown).

Nikkei Sangyo Shinbun (1975a). Shoden Kawasaki Kojo no Kakumaku-ho niyoru Kasei Soda Seizo

Setsubi Kansei - Jisha Gijutsu de Seisan Kaishi (Showa Denko Completes Construction of Caustic Soda Production Facilities with Diaphragm Process - Start of Production with Own Technology). Nikkei Sangyo Shinbun.

Nikkei Sangyo Shinbun (1975b). Tsurumi Soda, Soda Setsubi wo Isshin, Noryoku 20\% Appu (Tsurumi Soda Renews Soda Facilities, 20\% Increase in Capacity). Nikkei Sangyo Shinbun.

Nicolis, G. and I. Pregogine (1977). Self-Organization in Non-equilibrium Systems, (New York: John Wiley and Sons).

Nicolis, G. and I. Pregogine (1989). Exploring Complexity, (New York: W.H. Freeman)

Ostrom, E. (1999), "Institutional Rational Choice: An Assessment of the Institutional Analysis”, in Sabatier, P.A. (ed.) Theories of the Policy Process (Boulder CO: Westview Press), pp. 35-73

Palmer, K., Wallace E. Oates, and Paul R. Portney (1995). "Tightening Environmental Standards: The Benefit-Cost or the No-Cost Paradigm?" Journal of Economic Perspectives, 9 (4), 119-132.

Parto, S. (2003). “Transitions: An Institutionalist Perspective”, MERIT-Infonomics Research Memorandum Series (2003-019).

Parto, S. (2005a). "Economic Activity and Institutions: Taking Stock”. Forthcoming in the Journal of Economic Issues 39:1, 31-52.

Parto, S. (2005b). “’Good’ Governance and Policy Analysis: What of Institutions?”, MERIT/Infonomics Research Memorandum 2005-001.

Porter, Michael and Claas van der Linde (1995a). "Green and Competitive: Ending the Stalemate." Harvard Business Review, (September-October), 120-134.

Porter, Michael and Claas van der Linde (1995b). "Toward a New Conception of the EnvironmentCompetitiveness Relationship." Journal of Economic Perspectives, 9 (4), 97-118.

Rostow, W. (1960). The Stages of Growth: A Non-Communist Manifesto (London: Cambridge University Press).

Rotmans, J., R. Kemp, and M. van Asselt (2001). "More evolution than revolution: Transition management in public policy." The Journal of Futures Studies, Strategic Thinking and Policy. 3:1531.

Sabatier, P.A. and H.C. Jenkins-Smith (1999). Frameworks Focusing on Policy Change over Fairly Long Periods”, in Sabatier, P.A. (ed.), Theories of the Policy Process. (Boulder CO: Westview Press).

Shibata, Hiroshi, Y. Kokubu, and I. Okazaki (1977). "The Nobel Diaphragm Cell: A Flexible Design for High Currents and Its Performance Characteristics at $330 \mathrm{kA}$." Symposium on Diaphragm Cells for Chlorine Production, London, Society of Chemical Industry.

Showa Chemical (2001). "Nenpu (Chronology)." Showa Chemical.

Society of Chemical Engineers of Japan (1998). Kagaku Purosesu: Kiso kara Gijutsu Kaihatsu made (Chemical Processes: From Fundamentals to Technological Development). Tokyo: Tokyo Kagaku Dojin.

Takeshita, Tetsuo (1990). "Showa Denko Diaphragm Chlor-Alkali Technology." 33rd Chlorine Plant Operations Seminar and Workshop Sessions, Washington, D.C., Chlorine Institute.

Tokuyama (2002). "Research and Development Themes and Electrolytic Plants at Tokuyama." Tokuyama.

Tsubaki, Tadao and Katsuro Irukayama, eds. (1977). Minamata Disease: Methylmercury poisoning in Minamata and Niigata, Japan. Tokyo: Kodansha.

Tsurumi Soda (2001). "Kaisha Enkaku (Corporate Chronology)." Tsurumi Soda.

Yarime, Masaru (2003). "From End-of-Pipe Technology to Clean Technology: Effects of Environmental Regulation on Technological Change in the Chlor-Alkali Industry in Japan and Western Europe." Ph.D. Dissertation. University of Maastricht, The Netherlands. May 8. 